\title{
Wybrane elementy badań petrologicznych w dolomicie głównym złoża BMB
}

\author{
Katarzyna Jarmołowicz-Szulc ${ }^{1}$
}

\begin{abstract}
Selected issues of petrological research in the Main Dolomite of the BMB field. Prz. Geol., 67: 161-163; doi: 10.7306/2019.8
A b s $\operatorname{r}$ a c $t$. Based on the assumption that diversified fluids can be trapped in inclusions present in the rock cements of sedimentary basins, fluid inclusion studies were undertaken in the wells of the Barnówko-Mostno-Buszewo oil and gas field (western Poland). Sampling was conducted in six wells, and most samples studied lie at a depth interval of 3100 to $3150 \mathrm{~m}$. Methods applied in the present study stage comprised: standard petrography, microscopic analysis of fluid inclusions, fluorescence studies and some introductory microthermometric measurements. Three types of fluid inclusions were observed and studied: two-phase aqueous (brine) inclusions (non-fluorescent); two-phase oil inclusions (fluorescent); one-phase methane inclusions (non-fluorescent). These inclusions display either a primary or a secondary character. Their abundance and detailed characteristics differ depending on the type of mineral, well and depth position.
\end{abstract}

Keywords: oil and gas field, wells, fluid inclusions, hydrocarbons

Celem pracy jest prezentacja charakterystyki inkluzji fluidalnych (FI) zamkniętych w minerałach skał osadowych złoża Barnówko-Mostno-Buszewo (BMB), jak również przedstawienie możliwości interpretacji wyników badań fluorescencji tych wrostków. Zgodnie z teorią podawaną w licznych pracach (np. Goldstein, 2001), badania mikrotermometryczne dostarczają wiele danych temperaturowych, które zarówno w postaci surowej, jak i po przeliczeniach wg ogólnie stosowanych formuł i z użyciem dostępnych programów komputerowych (Bakker, Brown, 2003) mogą służyć do oceny warunków ciśnienia i temperatury procesów, które miały miejsce w historii geologicznej skały. Obecne opracowanie obejmuje analizę części bieżącego materiału badawczego i reinterpretację wyników przeprowadzonych wcześniej badań mikrotemperaturowych.

Założeniem podjęcia tematyki badań FI była konieczność określenia charakteru inkluzji zamykanych w wypełnieniach przestrzeni porowej w otworach wiertniczych BMB. Wytypowano otwory, które znajdują się w obrębie konturu występowania gazu i/ lub ropy naftowej. W wyborze kierowano się ich lokalizacją - przyjęto maksymalny zasięg rozprzestrzenienia - od skrajnie NE poprzez część centralną i wschodnią po SW i NW.

\section{BUDOWA GEOLOGICZNA OBSZARU}

Złoże BMB jest usytuowane w Wielkopolsce, na grzbiecie wolsztyńskim, w obrębie bloku Gorzowa. Wiercenia prowadzone od lat 90. ub.w. doprowadziły do odkrycia złoża ropy i gazu w utworach cechsztynu w poziomie dolomitu głównego (Ca2; Weil i in., 1994). Główną skałą zbiornikową, której miąższość waha się od 33 do ponad $80 \mathrm{~m}$, są węglany - wapienie i dolomity (Dyjaczyński i in., 2009). Krystaliczne dolomity odpowiadają poziomowi A najniższej części Ca2, gdzie wysoko rozwinięte procesy rekrystalizacji, rozpuszczania i anhydrytyzacji zatarły pierwotne struktury (Peryt, Dyjaczyński, 1991; Pikulski, Wolnowski, 2000). Niekiedy mogą być zachowane relikty onkolitów i intraklastów. W najniższej części występują cienkie wypełnienia anhydrytowe z mikrostylolitami, które zawierają bituminy. Rozpuszczanie węglanów i wtórne cementy siarczanowe są często widoczne. Ogółem charakter skał dolomitu głównego regionu określić można następująco: wapienie są ciemnoszare i czarne typu madstonów, dolomit jest przeważnie wykształcony jako oolitowe greinstony, niekiedy pakstony, na ogół zdolomityzowane. Dolomity wykazują dobre warunki zbiornikowe o porowatości w przedziałach 8-14\% (Mamczur i in., 1997; Pikulski, Wolnowski, 2000; Kosakowski, Krajewski, 2013). Na omawianym obszarze Wielkopolski utwory dolomitu głównego zapadają dość łagodnie w kierunku północno-wschodnim, a odkryte dotychczas złoża ropy naftowej i gazu ziemnego są związane z elewacjami Barnówka, Mostna, Buszewa, Gajewa, Różańska oraz Lubiszyna (Pikulski, 1998; Czekański i in., 2010).

\section{POBIERANIE PRÓBEK}

Próbki do badań inkluzji fluidalnych zostały pobrane w czerwcu 2018 r. w archiwum rdzeni wiertniczych PGNiG w Chmielniku. Pobrano 50 próbek rdzeni wiertniczych z 6 otworów wytypowanych na podstawie analizy dokumentacji archiwalnej PGNiG. Prace badawcze są w toku. Część prezentowanych obecnie wyników pochodzi także z materiałów archiwalnych Państwowego Instytutu Geologicznego - Państwowego Instytutu Badawczego (PIG-PIB). Ogółem próbki pochodzą z głębokości poniżej 3000 m, w przedziale od ok. 3033 do ok. 3357 m, w większości 3100-3150 m.

\section{METODYKA BADAŃ}

Badaniami objęto część materiału z otworów wiertniczych Mo 1, Bu 5, Bu 9, Bu 17, Mo 6, Ba 7. Prace prowadzono z użyciem mikroskopu Nikon Eclipse z dostawką fluorescencyjną i cyfrową rejestracją obrazu oraz stolika grzewczo-chłodzącego Linkam. Pomiary prowadzano pod mikroskopem z okularami 15×, używając na ogół obiektywów $10 \times, 20 \times$ i $40 \times$. Wcześniejsze oznaczenia były wykonywane na zestawie aparaturowym FLUID INC. sterowanym manualnie i zamontowanym na mikroskopie Leitz oraz pod mikroskopem NIKON z aparatem analogowym.

\footnotetext{
${ }^{1}$ Państwowy Instytut Geologiczny - Państwowy Instytut Badawczy, ul. Rakowiecka 4, 00-975 Warszawa; katarzyna.jarmołowicz-szulc@pgi.gov.pl
} 
Interpretacja asocjacji inkluzji jest oparta na podstawach proponowanych przez Goldsteina (2001). Grzanie i zamrażanie próbek na stoliku zamrażająco-grzewczym LINKAM przeprowadzano w zakresie temperatur na ogół od pokojowej $\left(19-29^{\circ} \mathrm{C}\right)$ do $100^{\circ} \mathrm{C}$ i do $-70^{\circ} \mathrm{C}$ w przypadku inkluzji „wodnych” (AQFI) i wypełnień węglowodorami ciężkimi (HCFI1) oraz do $-198^{\circ} \mathrm{C}$ w przypadku inkluzji zawierających węglowodory lekkie (HCFI2). Badania inkluzji fluidalnych wykonywano w węglanach i kwarcu, rzadziej w anhydrycie, i stosowano kroki analityczne podobne do prezentowanych przez np. Jarmołowicz-Szulc (2016).

\section{WYNIKI WSTĘPNE I DYSKUSJA}

Prezentowane wyniki wstępne pochodzą częściowo z materiału $\mathrm{z}$ otworów wiertniczych Mo $1, \mathrm{Mo} \mathrm{6,} \mathrm{Bu} \mathrm{5,} \mathrm{Bu} \mathrm{9,}$ $\mathrm{Bu} 17, \mathrm{Ba} 7$, a także $\mathrm{z}$ danych archiwalnych (pojedyncze próbki $\mathrm{z}$ otworów $\mathrm{Bu} 16, \mathrm{Bu} 13, \mathrm{Bu} 12$ ). Badania inkluzji fluidalnych przeprowadzano w węglanach (kalcyt, dolomit) i kwarcu, rzadziej w anhydrycie czy fluorycie. We wszystkich próbkach badano świecenie fluidów w zakresie nadfioletu w świetle lampy kwarcowej. Fluorescencja stanowiła narzędzie wstępnej diagnozy inkluzji węglowodorowych (patrz: Jarmołowicz-Szulc, 2016). W przypadku metanu oczekiwano braku wzbudzenia (lub nikłego niebieskawego świecenia), podobnie jak w inkluzjach zawierających solankę. Dla rozróżnienia tych niefluoryzujących typów fluidów zamkniętych we wrostkach - w pierwszym przybliżeniu - istotna była obserwacja fazowości inkluzji (inkluzje jednofazowe i dwufazowe). W niektórych próbkach przeprowadzono wstępne badania mikrotermometryczne (oznaczenia temperatury homogenizacji/eutektyku/topnienia lodu).

\section{Charakterystyka inkluzji fluidalnych}

W części próbek zaobserwowano wyraźne świecenie inkluzji fluidalnych w barwach białoniebieskich, niekiedy żółtawych (ryc. 1). Inkluzje mają charakter dwufazowy. Znajdują się w spoiwie różnego typu, różna też jest ich obfitość. Obecność fluoryzujących inkluzji jest najbardziej charakterystyczna dla dolomitu i anhydrytu w otworze
Bu 16, fluorytu - Bu 13 oraz kalcytu - Bu 9. Dwufazowe inkluzje, które wykazują fluorescencję, są niewątpliwie inkluzjami węglowodorowymi - węglowodorów ciężkich (HCFI1). Występują one w kryształach w różnej pozycji, a mianowicie:

- w strefach liniowych tnących poszczególne kryształy, często w asocjacji z nagromadzeniami stałych wrostków bitumicznych;

- układają się w liniach naśladujących kierunki krystalograficzne minerału (np. dolomit Buszewo 16);

- tworzą chmury genetycznie powiązane $\mathrm{z}$ minerałem gospodarzem.

W cementach występują także inkluzje, które nie wykazują fluorescencji, bądź mają one nikłą barwę niebieskawą.

\section{Mikrotermometria}

Badania temperaturowe prowadzone dla różnych typów spoiw i próbek $\mathrm{z}$ otworów wiertniczych $\mathrm{z}$ rejonu $\mathrm{BMB}$ z głębokości od 3121,6 m (Ba 7) do 3141,85 m (Bu 13) pokazują, że temperatury homogenizacji inkluzji dwufazowych mieszczą się w różnym zakresie dla roztworów solankowych i węglowodorów. Na ogół dotychczas zbadane dwufazowe inkluzje ropy homogenizują w przedziale temperatur $106-145^{\circ} \mathrm{C}$, przy czym maksimum częstości odpowiada wartościom $128-138^{\circ} \mathrm{C}$. Uzyskane dotychczas temperatury homogenizacji inkluzji roztworów wodnych mieszczą się w szerokim przedziale wartości, co wymaga zdecydowanego uściślenia. Generalnie - niekiedy zaznacza się tendencja wyższych wartości dla współwystępujących AQFI niż dla HCFI.

Temperatura eutektyku określona w niektórych inkluzjach ogólnie odpowiada następującym zakresom wartości: -60 do $-50^{\circ} \mathrm{C}$ (dolomit, kalcyt); -49 do $-47^{\circ} \mathrm{C}$ (anhydryt) oraz -40 do $-34^{\circ} \mathrm{C}$ (dolomit, kwarc). Po zamrożeniu w kalcytach pojawia się zbrązowienie. Ostatnią fazę topniejącą stanowi lód. Jego finalne topnienie lodu odpowiadające powyższym wartościom i różnym minerałom zachodzi w niskich i zróżnicowanych przedziałach temperaturowych, a mianowicie: -19 do $-13^{\circ} \mathrm{C}$ (kalcyt, dolomit wachlarzowaty) oraz $-6,5^{\circ} \mathrm{C}$ (dolomit mozaikowy); ok.
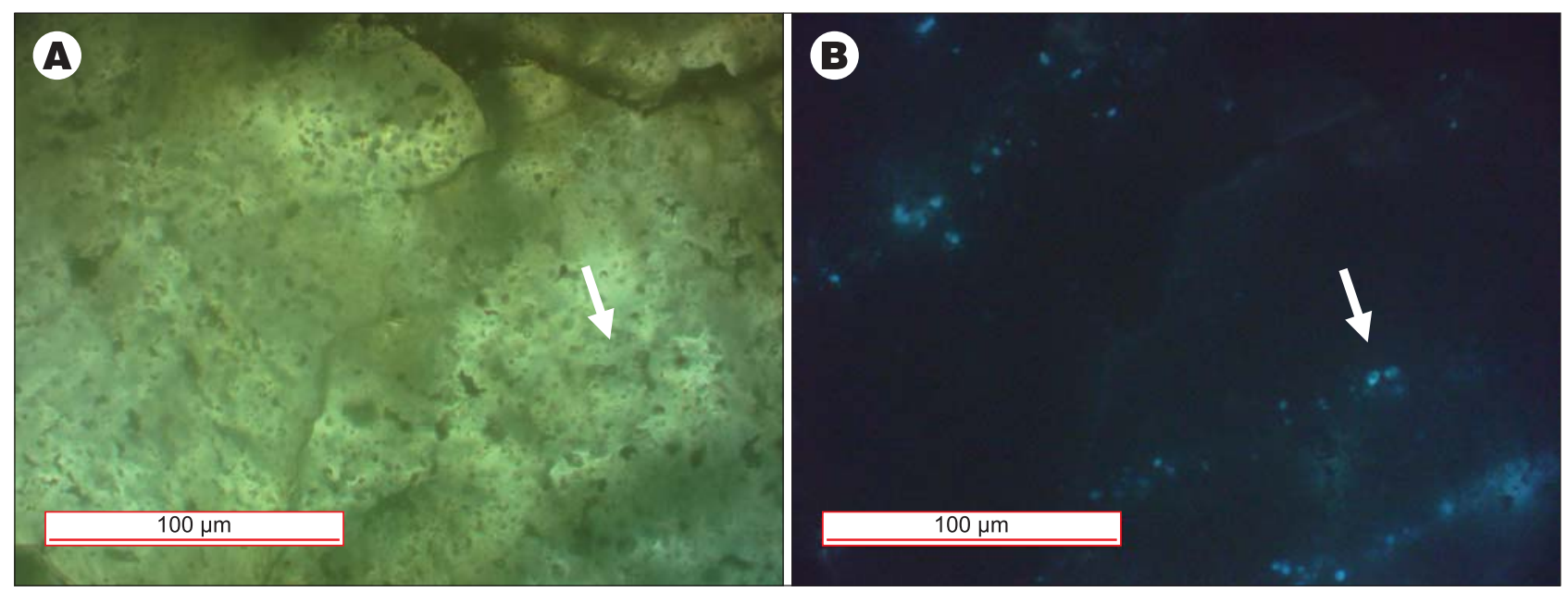

Ryc. 1. Inkluzje fluidalne w otworze Bu 5 (próbka Ch5a). A - inkluzje dwufazowe, obraz w świetle przechodzącym spolaryzowanym, jeden nikol; B - fluorescencja niektórych inkluzji fluidalnych w barwach niebieskobiałych, obraz w świetle odbitym, nadfiolet. Strzałki wskazują przykładowo analogiczną asocjację inkluzji

Fig. 1. Fluid inclusions in well $\mathrm{Bu} 5$ (sample Ch5a). A - two-phase fluid inclusions, image in transmitted light, plane-polarized light; B - blue-white fluorescence of some fluid inclusion assemblages, image in reflected light, ultraviolet. Arrows point to the similar fluid inclusion assemblage as an example 
Tab. 1. Charakterystyka węglowodorów na podstawie badań inkluzji w dolomicie i kalcycie Table 1. Characteristics of hydrocarbons based on fluid inclusion studies in dolomite and calcite

\begin{tabular}{|c|c|c|c|c|c|c|}
\hline $\begin{array}{l}\text { Mineral / próbka } \\
\text { Mineral / sample }\end{array}$ & $\begin{array}{c}\text { Barwa świecenia } \\
\text { Fluorescence colour }\end{array}$ & $\begin{array}{c}\text { Układ FI } \\
\text { FI distribution }\end{array}$ & $\begin{array}{l}\text { Charakter inkluzji } \\
\text { Inclusion character }\end{array}$ & $\begin{array}{l}\text { Parametr } Q^{*} \\
Q^{*} \text { parameter }\end{array}$ & $\begin{array}{c}\text { Wartości }{ }^{\circ} \mathrm{API} * \\
{ }^{\circ} \mathrm{API}{ }^{*} \text { values }\end{array}$ & $\begin{array}{c}\text { Charakter } \\
\text { węglowodorów / (Th) } \\
\text { Character of } H C /(T h)\end{array}$ \\
\hline $\begin{array}{l}\text { Dolomit / } \\
\text { Bu } 16-1 \\
\text { Dolomite }\end{array}$ & $\begin{array}{l}\text { białoniebieska } \\
\text { white-blue }\end{array}$ & $\begin{array}{l}\text { liniowy; zgodnie } \\
\text { z płaszczyznami } \\
\text { linear; parallel } \\
\text { to crystal planes }\end{array}$ & $\begin{array}{l}\text { pierwotne } \\
\text { primary }\end{array}$ & $0,2-0,1$ & $41-42$ & $\begin{array}{c}\text { ropa lekka, parafinowa, } \\
\text { dojrzała / } \\
\left(126,0-135,0^{\circ} \mathrm{C}\right) \\
\text { light, mature, paraffin oil }\end{array}$ \\
\hline $\begin{array}{l}\text { Kalcyt / } \\
\text { Bu } 9-11 \\
\text { Calcite }\end{array}$ & $\begin{array}{l}\text { białoniebieska } \\
\text { white-blue }\end{array}$ & $\begin{array}{l}\text { sporadyczne } \\
\text { grupy } \\
\text { sporadic FIAs }\end{array}$ & $\begin{array}{l}\text { wtórne } \\
\text { secondary }\end{array}$ & 0,2 & $>41$ & $\begin{array}{c}\text { ropa lekka, parafinowa, } \\
\text { dojrzała } / \\
\left(114,5-130,0^{\circ} \mathrm{C}\right) \\
\text { light, mature, paraffin oil }\end{array}$ \\
\hline
\end{tabular}

* Oszacowane na podstawie odczytów z tabeli estymacji (wg Jarmołowicz-Szulc, 2017)

* Based on readings using the estimation table (after Jarmołowicz-Szulc, 2017)

$-17^{\circ} \mathrm{C}$ (anhydryt); od $-11,4$ do $-7,8^{\circ} \mathrm{C}$ (dolomit) oraz od $-6,8$ do $-4,3^{\circ} \mathrm{C}$ (kalcyt). Temperatury eutektyku poniżej $-21^{\circ} \mathrm{C}$ wskazują na obecność jonów wapnia lub magnezu wraz z NaCl we fluidzie (por. Goldstein, Reynolds, 1994). Wartości ok. $-56 \mathrm{i}-40^{\circ} \mathrm{C}$ wskazują na układ $\mathrm{NaCl}-\mathrm{CaCl}_{2}-\mathrm{MgCl}_{2}-\mathrm{H}_{2} \mathrm{O}$, co oznacza system chemiczny rozpuszczonych jonów $\mathrm{Cl}^{-}, \mathrm{Ca}^{2+}, \mathrm{Mg}^{2+}, \mathrm{Na}^{+}$. Uzyskane wartości można interpretować jako procent ekwiwalentny $\mathrm{NaCl}$ (Shepherd i in., 1985; Jarmołowicz-Szulc, 2015), jak też odnosić do \% ekw. $\mathrm{CaCl}_{2}$ (Jarmołowicz-Szulc, 2015, 2017). Jednak dla pełniejszego obrazu zmienności i dalszej interpretacji konieczne jest określenie szczegółowego następstwa poszczególnych faz minerałów.

\section{PODSUMOWANIE I WNIOSKI}

Chociaż badane minerały pochodzą z dużej głębokości (ok. $3100 \mathrm{~m}$ ) i są podatne na wpływ czynników zewnętrznych - ciśnienia i temperatury, mogły zachować niektóre cechy pierwotne. Badania inkluzji fluidalnych w skałach dolomitu głównego największego polskiego złoża ropy i gazu Barnówko-Mostno-Buszewo (BMB) pozwalają na wyciągnięcie następujących wstępnych wniosków:

- inkluzje o charakterze solankowym/wodnym (AQFI) niekiedy współwystępują z inkluzjami węglowodorowymi ( HCFI) w minerałach;

- węglowodory są obecne w postaci inkluzji w różnych typach spoiw w skałach;

- pierwotne inkluzje węglowodorowe (HCFI1, HCFI2) są dość liczne w dolomicie i kalcycie, mniej liczne w anhydrycie i fluorycie;

- ich obecność wskazuje na migrację/obecność węglowodorów w regionie;

- inkluzje węglowodorowe są związane z procesami diagenetycznymi, tzn. są późniejsze niż pierwotne wypełnienie złoża;

- fluidy typu solanki są zróżnicowane co do składu chemicznego i zasolenia;

- pierwotne nagromadzenia obu rodzajów inkluzji w kryształach (np. w kalcycie) wskazują na wspólny front węglowodorowo-solankowy, podczas gdy wtórna pozycja inkluzji jest dowodem migracji węglowodorów późniejszej niż tworzenie cementu. Charakterystyka fluorescencji inkluzji dwufazowych wskazuje na ich wypełnienie ropa naftową (tab. 1). Na podstawie barwy świecenia można szacunkowo określić cechy tej ropy w inkluzjach (por. Jar-
mołowicz-Szulc, 2017). W większości przypadków jest to ropa lekka, dojrzała.

Autorka składa serdeczne podziękowanie dyrekcji PGNiG za udostępnienie próbek do badań oraz zgodę na niniejszą publikację. Recenzja niniejszej pracy wykonana została przez prof. Tadeusza Peryta.

\section{LITERATURA}

BAKKER R.J., BROWN P.E. 2003 - Computer modeling in fluid inclusion research. [W:] Samson I., Anderson A., Marshall D. (red.), Fluid inclusions: analysis and interpretation. Short Course. Mineral. Assoc. Can., 32: 185-203.

CZEKAŃSKI E., KWOLEK K., MIKOŁAJEWSKI Z. 2010 - Złoża węglowodorów w utworach cechsztyńskiego dolomitu głównego (Ca2) na bloku Gorzowa. Prz. Geol., 58: 695-703.

DYJACZYŃSKI K., KWOLEK K., MIKOŁAJEWSKI Z., PERYT T.M., SŁOWAKIEWICZ M. 2009 - Microplatforms of the Main Dolomite $(\mathrm{Ca} 2)$ in western Poland in the aspect of hydrocarbon prospection. $6^{\text {th }}$ Annual Conference of SEPM-CES SEDIMENT, 24-25 June 2009, Kraków: 14-15.

GOLDSTEINR.H. 2001 - Fluid inclusions in sedimentary and diagenetic systems. Lithos, 55: 159-193.

GOLDSTEIN R.H., REYNOLDS T.J. 1994 - Systematics of fluid inclusions in diagenetic minerals. SEPM Short Course 31, Tulsa.

JARMOŁOWICZ-SZULC K. 2015 - Analiza inkluzji fluidalnych w minerałach skał osadowych w Polsce - przegląd i uwagi. Biul. Państw. Inst. Geol., 464: 25-41.

JARMOŁOWICZ-SZULC K. 2016 - Inkluzje węglowodorowe w spoiwach skał osadowych i minerałach żyłowych - charakterystyka i znaczenie. Biul. Państw. Inst. Geol., 466: 87-101.

JARMOŁOWICZ-SZULC K. 2017 - Estimation of oil characteristics: results based on fluorescence phenomenon and fluid inclusion synthesis and analysis. Inter. J. Curr. Advanc. Res., 6: 2014-2021.

KOSAKOWSKI P., KRAJEWSKI M. 2013 - Hydrocarbon potential of the Zechstein Main Dolomite in the western part of the Wielkopolska platform, SW Poland: New sedimentological and geochemical data. Marin. Petrol. Geol., 49: 99-120.

MAMCZUR S., RADECKI S., WOJTKOWIAK Z. 1997 - O największym złożu ropy naftowej w Polsce Barnówko-Mostno-Buszewo (BMB). Prz.Geol., 45: 582-588.

PERYT T.M., DYJACZYŃSKI K. 1991 - An isolated carbonate bank in the Zechstein Main Dolomite Basin in western Poland. J. Petrol. Geol., 14: 445-458.

PIKULSKI L. 1998 - Sedymentacja oraz rozwój litofacjalny utworów dolomitu głównego (Ca2) w rejonie złoża Barnówko-Mostno-Buszewo (BMB), zachodnia Polska. Prz. Geol., 46: 426-435.

PIKULSKI L., WOLNOWSKI T. 2000 - Geological analysis of the main Dolomite Formation (Ca2) in Western Poland. American Association of Petroleum Geologists Search and Discovery Article. AAPG/EAGE International Research Conference, El Paso, Texas, Oct. 1-5, 2000, p. 53.

SHEPHARD T.J., RANKIN A.H., ALDERTON D.H. 1985 - A practical guide to FI studies. Blackie. New York.

WEIL W., RADECKI S., KARNKOWSKI P., JASTRZĘBSKI M. $1994-$ Poszukiwanie ropy naftowej i gazu ziemnego w 1993 roku i zamierzenia na przyszłość. Nafta-Gaz, 50: 227-233. 